\title{
Functionalization of thermo-acid activated sepiolite by amine-silane and mercapto-silane for chromium(VI) adsorption from aqueous solutions
}

\author{
Vesna M. Marjanovići ${ }^{2}$ Slavica S. Lazarević' ${ }^{2}$ Ivona M. Janković-Častvan², Bojan M. Jokić², \\ Anđelika Z. Bjelajac ${ }^{2}$, Đorđe T. Janaćković ${ }^{2}$, Rada D. Petrović ${ }^{2}$ \\ ${ }^{1}$ High Business-Tehnical School of Užice, 31000 Užice, Trg Sv. Save 34, Serbia \\ ${ }^{2}$ Faculty of Technology and Metallurgy, University of Belgrade, 11000 Belgrade, Karnegijeva 4, Serbia
}

\begin{abstract}
Chromium(VI) adsorption from aqueous solutions onto thermo-acid activated sepiolite functionalized with (3-mercaptopropyl)trimethoxy-silane and [3-(2-aminoethylamino)propyl]trimethoxy-silane was investigated. Scanning electron microscopy, X-ray diffraction, Fourier transform infrared spectroscopy, thermogravimetric and differential thermal analysis, nitrogen adsorption-desorption, and determination of the point of zero charge were used to characterize the obtained adsorbents. It has been established that the silanes were successfully grafted on the thermo-acid activated sepiolite surfaces and that the structure of parent material was preserved during the functionalization. The adsorption of $\mathrm{Cr}(\mathrm{VI})$ onto functionalized thermo-acid activated sepiolite was tested as a function of initial $\mathrm{pH}$ values at $298 \mathrm{~K}$. The amine functionalized thermo-acid activated sepiolite showed a higher adsorption capacity than the mercapto functionalized thermo-acid activated sepiolite at all studied initial $\mathrm{pH}$ values, especially at the initial $\mathrm{pH} 2$.
\end{abstract}

Keywords: thermo-acid activated sepiolite, functionalization, (3-mercaptopropyl)trimethoxy-silane, [3-(2-aminoethylamino)propyl]trimethoxy-silane, adsorption, chromium(VI).

SCIENTIFIC PAPER

UDC 546.766:66.081.3:546.281:547.7

Hem. Ind. 67 (5) 715-728 (2013)

doi: 10.2298/HEMIND121026117M

Available online at the Journal website: http://www.ache.org.rs/HI/

In the environment, chromium originates from geochemical and anthropogenic sources (industry, energy, mines and smelters). The most stable forms of chromium in the environment are trivalent chromium, $\mathrm{Cr}(\mathrm{III})$, and hexavalent chromium, $\mathrm{Cr}(\mathrm{VI})$, whereas $\mathrm{Cr}(\mathrm{VI})$ is more toxic, carcinogenic and mutagenic to the living organisms [1]. In aqueous solutions, $\mathrm{Cr}(\mathrm{VI})$ occurs in several stable forms, such as: $\mathrm{Cr}_{2} \mathrm{O}_{7}{ }^{2-}, \mathrm{H}_{2} \mathrm{CrO}_{4}, \mathrm{HCrO}_{4}{ }^{-}$ and $\mathrm{CrO}_{4}{ }^{2-}$. The relative abundance of those forms mainly depends on the $\mathrm{pH}$ value of the solution and $\mathrm{Cr}(\mathrm{VI})$ concentration. $\mathrm{H}_{2} \mathrm{CrO}_{4}$ generally exists at $\mathrm{pH}$ less than about 1.0; $\mathrm{HCrO}_{4}^{-}$predominates at $\mathrm{pH}$ values between 2.0 and 6.0; and when $\mathrm{pH}$ increases to above 6.8, $\mathrm{CrO}_{4}{ }^{2-}$ is the primary form. The dichromate ion, $\mathrm{Cr}_{2} \mathrm{O}_{7}{ }^{2-}$, forms when the concentration of chromium exceeds approximately $1 \mathrm{~g} / \mathrm{dm}^{3}$ [1].

A simple, effective and inexpensive method for the $\mathrm{Cr}(\mathrm{VI})$ removal from aqueous solutions, like polluted water, is the adsorption, where the key factor is the selection of a proper adsorbent. The adsorption of $\mathrm{Cr}(\mathrm{VI})$ oxyanions from aqueous solutions by natural clay minerals was not given much attention, mainly due to the fact that clays are negatively charged and moreover unfunctionalized clay mineral surface shows no affinity for $\mathrm{Cr}(\mathrm{VI})$ oxyanions [2]. In order to use natural clay

Correspondence: R.D. Petrović, University of Belgrade, Faculty of Technology and Metallurgy, 11000 Belgrade, Serbia.

E-mail: radaab@tmf.bg.ac.rs

Paper received: 26 October, 2012

Paper accepted: 10 December, 2012 minerals for the adsorption of anionic species of $\mathrm{Cr}(\mathrm{VI})$ from aqueous solutions, it is necessary to change the character of their surface, which can be achieved via functionalization processes by adsorption of quarternary ammonium salts or amines and by organosilane grafting, through reaction with surface silanol groups. The study of $\mathrm{Cr}(\mathrm{VI})$ adsorption from aqueous solutions by functionalized clay minerals (kaolinite, montmorillonite, stevensite, rectorite, etc.) was the object of several researches [3-12]. To the best of our knowledge, there are no studies about $\mathrm{Cr}(\mathrm{VI})$ removal from aqueous solutions by functionalized sepiolite, except our previous studies, where natural and acid activated sepiolites were functionalized by using (3-mercaptopropyl)trimethoxy-silane [13] and [3-(2-aminoethylamino)propyl]trimethoxy-silane [14]. It was shown that functionalized partially acid activated sepiolite has a higher degree of functionalization and a higher adsorption capacity for anionic species of $\mathrm{Cr}(\mathrm{VI})$ compared to functionalized natural sepiolite $[13,14]$.

Our further studies were directed to the investigation of the removal of $\mathrm{Cr}(\mathrm{VI})$ by using fully-acid activated sepiolite functionalized with both (3-mercaptopropyl)trimethoxy-silane and [3-(2-aminoethylamino)propyl]trimethoxy-silane. It was shown [15-19] that during acid treatments of sepiolite, variable amounts of structural $\mathrm{Mg}^{2+}$ were removed, depending on the intensity of the acid treatment. If the treatment is aggressive enough, as during acid activation at elevated temperature, the octahedral cations are completely dissolved, 
while the tetrahedral sheets form free amorphous silica of high surface area and high mesoporosity [20]. It was expected that high density of silanol groups on the surface of thusly activated sepiolite can provide good functionalization through reaction between surface silanol groups and alkoxyl groups of organosilane $\mathrm{R}^{\prime}-\left(\mathrm{CH}_{2}\right)_{3}-\mathrm{SiX}_{3}$, where $\mathrm{X}$ is alkoxyl group (usually methoxy, $-\mathrm{OCH}_{3}$, or ethoxy, $-\mathrm{OC}_{2} \mathrm{H}_{5}$ ) and $\mathrm{R}^{\prime}$ is reactive vinyl $\left(-\mathrm{HC}=\mathrm{CH}_{2}\right)$, amine $\left(-\mathrm{NH}_{2}\right)$ or mercapto $(-\mathrm{SH})$ groups.

In this study, the influence of type of functionalization of fully-acid activated sepiolite on its physicochemical properties and $\mathrm{Cr}(\mathrm{VI})$ adsorption from aqueous solutions of the produced materials was investigated. Physicochemical characterization of the adsorbents was performed using $\mathrm{N}_{2}$ adsorption, FTIR, DTA, SEM and XRD measurements, as well as by determination of the point of zero charge. $\mathrm{Cr}(\mathrm{VI})$ adsorption was studied at different initial $\mathrm{pH}$ values and the dominant mechanisms of adsorption were proposed.

\section{MATERIALS AND METHODS}

\section{Starting material}

A fraction $<250 \mu \mathrm{m}$ of natural sepiolite (SEP) from Andrići, Čačak (Serbia), was used as the starting material [15]. An acid treatment was performed at elevated temperature (thermo-acid activation) as follows [20]: $10 \mathrm{~g}$ of sepiolite was suspended in $100 \mathrm{~cm}^{3}$ of 4 $\mathrm{mol} / \mathrm{dm}^{3} \mathrm{HCl}$ solution and heated at $65 \pm 1{ }^{\circ} \mathrm{C}$ in a stirred reaction flask for $10 \mathrm{~h}$. Then, the mixture was filtered, washed with hot distilled water until it became $\mathrm{Cl}^{-}$free and dried at $110{ }^{\circ} \mathrm{C}$ for $2 \mathrm{~h}$. Hereinafter, sepiolite activated by acid at elevated temperature was marked as TASEP.

With the determination of the chemical composition of TASEP by AAS, Perkin Elmer 730 (89.6 wt.\% $\mathrm{SiO}_{2}, 0.12$ wt.\% MgO, $<0.03$ wt. $\% \mathrm{Al}_{2} \mathrm{O}_{3}, 0.08$ wt.\% $\mathrm{Fe}_{2} \mathrm{O}_{3},<0.05$ wt.\% $\mathrm{CaO}$ and 8.66 wt.\% LOI) it was shown that there was almost complete magnesium leaching from sepiolite structure during applied thermo-acid activation.

\section{Functionalization of the thermo-acid activated sepiolite by organosilane}

The TASEP sample was functionalized with organosilane, $99.99 \%$ purity, manufactured by Sigma-Aldrich: i) (3-Mercaptopropyl)trimethoxysilane ( $\mathrm{HS}-\left(\mathrm{CH}_{2}\right)_{3}-\mathrm{Si}-$ $\left.-\left(\mathrm{OCH}_{3}\right)_{3}\right)$ or shortly named mercapto-silane and ii) [3-(2-aminoethylamino)propyl]trimethoxy-silane or amine-silane, with the chemical formula $\left(\mathrm{CH}_{3} \mathrm{O}\right)_{3} \mathrm{Si}-$ $-\left(\mathrm{CH}_{2}\right)_{3}-\mathrm{NH}-\left(\mathrm{CH}_{2}\right)_{2}-\mathrm{NH}_{2}$. The functionalization reactions were performed according to previous studies $[13,14]$. The mercapto and amine functionalized samples were denoted as MTASEP and APT-TASEP, respectively.

\section{Characterization}

The morphology of the TASEP, MTASEP and APT-TASEP powders was analysed by scanning electron microscopy (SEM) on a TESCAN MIRA 3 XMU microscope operating at $20 \mathrm{kV}$.

The phase compositions of TASEP, MTASEP and APT-TASEP were determined using a conventional powder diffractometer (Ital Structures APD 2000) with Bragg-Brentano geometry and $\mathrm{CuK}_{\alpha 1,2}$ radiation (Ni filter) with a $0.02^{\circ} 2 \theta$ step and a 2 s counting time per data point.

FT-IR analyses of the samples were performed on a $100 \mathrm{MB}$ Boman Hartmann \& Brown instrument in the wave number range from 400 to $4000 \mathrm{~cm}^{-1}$. The samples were prepared by the $\mathrm{KBr}$ method, at a ratio of the sample: $\mathrm{KBr}=1: 100$.

Simultaneous thermogravimetric and differential thermal analysis (TG/DTA) of the samples (approximately $5 \mathrm{mg}$ ) were performed in a flowing air atmosphere using a TA thermogravimetric analyzer (TA Instruments, New Castle, USA), model SDT Q600. The samples were heated up to $1000^{\circ} \mathrm{C}$ at a heating rate of $20^{\circ} \mathrm{C} / \mathrm{min}$.

The specific surface area, pore volume and pore size distribution of the samples were determined on the basis of nitrogen adsorption-desorption isotherms, using a Micromeritics ASAP 2020 instrument for measurements. Before the sorption measurement, the samples were degassed at $150{ }^{\circ} \mathrm{C}$ for $12 \mathrm{~h}$, in vacuum. Then, adsorption of nitrogen (purity $99.9 \%$ ) on the free surfaces of the samples was performed at a temperature of liquid nitrogen $\left(-196^{\circ} \mathrm{C}\right)$. Desorption of nitrogen was carried out at liquid nitrogen temperature. The specific surface area of each sample was calculated according to the Brunauer-Emmett-Teller (BET) method from the linear part of the nitrogen adsorption isotherm. The volume of the mesopores and pore size distribution were calculated according to the Barrett, Joyner and Halenda method [21] from the desorption branch of isotherm. The Dubinin-Radushkevich method [22] was used for analyzing of micropores.

The point of zero charge of the samples was determined using previously described batch equilibration technique $[13-15,23]$ in $\mathrm{KNO}_{3}$ solution (concentration 0.1 or $0.01 \mathrm{~mol} / \mathrm{dm}^{3}$ ). In all experiments, a series of samples of $25 \mathrm{~cm}^{3} \mathrm{KNO}_{3}$ solution, with the concentration of 0.1 and $0.01 \mathrm{~mol} / \mathrm{dm}^{3}$ and the preset adjusted $\mathrm{pH}$ values $\left(\mathrm{pH}_{\text {initial }}\right)$ of approximately 2.0 to approximately 11.0 , were equilibrated with $0.05 \mathrm{~g}$ of sepiolite sample, during $24 \mathrm{~h}$ at $25^{\circ} \mathrm{C}$ with constant shaking. In the case of TASEP and MTASEP samples, equilibration was performed for the two ratios of solid/liquid $(0.05$ and $0.10 \mathrm{~g} / 25 \mathrm{~cm}^{3}$ ). After achieving equilibrium, the suspensions were filtered through filter paper, and the 
$\mathrm{pH}$ value of the filtrate $\left(\mathrm{pH}_{\text {final }}\right)$ was measured. The point of zero charge $\left(\mathrm{pH}_{\mathrm{pzc}}\right)$ was determined from the dependence of the $\mathrm{pH}_{\text {final }}$ vs. $\mathrm{pH}_{\text {initial, }}$ as the $\mathrm{pH}$ value of plateau or as the $\mathrm{pH}$ value of the curve inflexion [13$-15,23]$.

\section{Adsorption experiments}

The aqueous solutions of $\mathrm{Cr}(\mathrm{VI})$ anions were prepared by dissolving $\mathrm{K}_{2} \mathrm{Cr}_{2} \mathrm{O}_{7}$, in demineralized water.

The $\mathrm{Cr}(\mathrm{VI})$ adsorption was investigated at batch conditions at a constant temperature in a thermostat with a shaker (MEMMERT), where the temperature was maintained at $25 \pm 0.01{ }^{\circ} \mathrm{C}$. The measured mass quantities of MTASEP or APT-TASEP were mixed with solutions of $\mathrm{Cr}(\mathrm{VI})$, at the preset $\mathrm{pH}$ values $\left(\mathrm{pH}_{\text {initial }}\right)$ in PVC vessels. Upon expiration of the required mixing time in the thermostat, the suspensions were filtered and further, the concentrations of $\mathrm{Cr}(\mathrm{VI})$ in solution and the final $\mathrm{pH}$ value of the solution $\left(\mathrm{pH}_{\text {final }}\right)$ were determined. In order to determinate the concentration of $\mathrm{Cr}(\mathrm{VI})$ in the solution, atomic absorption spectroscopy (AAS) was performed using a Perkin Elmer 730 instrument, while the $\mathrm{pH}$ value of the solution was measured by a $\mathrm{pH}$ meter (InoLab WTW series $\mathrm{pH} 720$ ). To adjust the initial $\mathrm{pH}$ values of solutions, solutions of $\mathrm{HCl}$ or $\mathrm{KOH}$ of 0.1 $\mathrm{mol} / \mathrm{dm}^{3}$ concentration were used.

The adsorption of $\mathrm{Cr}(\mathrm{VI})$ on MTASEP or APT-TASEP was investigated at different initial concentrations of $\mathrm{Cr}(\mathrm{VI})$ solution of 5 to $205 \mathrm{mg} / \mathrm{dm}^{3}$ and at different initial $\mathrm{pH}$ values: $4.5,3.0$ and $2.0 \pm 0.1$. The ratio of adsorbent/solution was $0.10 \mathrm{~g} / 25 \mathrm{~cm}^{3}$ for MTASEP and $0.05 \mathrm{~g} / 25 \mathrm{~cm}^{3}$ for APT-TASEP.

The amounts of $\mathrm{Cr}(\mathrm{VI})$ ions adsorbed per unit mass of functionalized sepiolite were calculated using Eq. (1):

$q_{\mathrm{e}}=\frac{c_{\mathrm{i}}-c_{\mathrm{e}}}{w} V$

where: $c_{\mathrm{i}}$ - initial concentration of $\mathrm{Cr}(\mathrm{VI})$ in solution $\left(\mathrm{mg} / \mathrm{dm}^{3}\right) ; c_{\mathrm{e}}$ - the equilibrium concentration of $\mathrm{Cr}(\mathrm{VI})$ in solution $\left(\mathrm{mg} / \mathrm{dm}^{3}\right) w-$ mass of adsorbent $(\mathrm{g}), V-$ volume of $\mathrm{Cr}(\mathrm{VI})$ solution $\left(\mathrm{dm}^{3}\right)$.

All adsorption experiments were repeated twice. The presented results represent the mean of two measurements.

\section{RESULTS AND DISCUSSION}

\section{Characterization of the unfunctionalized and functionalized thermo-acid activated sepiolites}

Figure 1 shows micrographs of TASEP (a), MTASEP (b) and APT-TASEP (c). It can be seen that the thermoacid activated sepiolite (TASEP) has a fibrous structure (Figure 1a) like a natural sepiolite [24], but the difference is that TASEP fibres are shorter (Figure 1a). What is more, the fibre structure of MTASEP and APT-TASEP samples was preserved during functionalization (Figure $1 b$ and $c)$, whereby the fibres were more connected comparing to the parent material (Figure 1a).

The diffraction patterns of TASEP, MTASEP and APTTASEP are given in Figure 2. The X-ray diffractogram of the TASEP sample shows almost completely amorphous structure. The appearance of the broad diffraction peak at $2 \theta=23^{\circ}$ indicates the formation of amorphous silica. There are no differences between diffractograms of functionalized (MTASEP and APT-TASEP) and parent sample (TASEP), which indicates that functionalized samples retained the structure of unfunctionalized one.

FT-IR spectra of the TASEP, MTASEP and APT-TASEP samples are shown in Figure 3 . The spectrum of MTASEP is very similar to the spectrum of TASEP, but there is the difference in the intensity of the bands in the $2950-2840 \mathrm{~cm}^{-1}$ range, which can be assigned to vibration of $\mathrm{C}-\mathrm{H}$ bonds in mercapto-silane [13,14,25-27].

Also, FT-IR spectrum of APT-TASEP is generally similar to FT-IR spectrum of TASEP, but the intensity of the bands in the $2950-2840 \mathrm{~cm}^{-1}$ range in the spectrum of APT-TASEP is higher than in the spectrum of TASEP. In addition, there is a band at around $1500 \mathrm{~cm}^{-1}$, which is characteristic of amine groups in amine-silane [25,28$-34]$.

In order to assess the differences between the functionalized and unfunctionalized samples, the results of FT-IR spectroscopy of TASEP, MTASEP and APT-TASEP were presented in the range between 3200 and 2500 $\mathrm{cm}^{-1}$ (Figure 4).

From the Figure 4, it can be seen that there are the bands at about 2936 and $2857 \mathrm{~cm}^{-1}$ which can be assigned to the $\mathrm{C}-\mathrm{H}$ vibration of methoxy $\left(\mathrm{OCH}_{3}\right)$ and methylene $\left(\mathrm{CH}_{2}\right)$ groups, respectively $[13,14,25-27]$. These bands cannot be observed in the FT-IR spectrum of TASEP. The presence of methoxy groups in the functionalized samples indicates that the silanes do not bind to the surface by reaction of all (three) methoxy groups, but probably by reaction of one $\mathrm{OCH}_{3}$ with one silanol group at the surface of TASEP [26,35]. The intensities of the both bands are higher for APT-TASEP than for MTASEP, which indicates that the content of $\mathrm{CH}_{2}$ and $\mathrm{OCH}_{3}$ groups is higher in APT-TASEP than in MTASEP, supposing it is due to the fact that the aminesilane contains five $\mathrm{CH}_{2}$ groups, while mercapto-silane contains only three. However, higher content of $\mathrm{OCH}_{3}$ groups in APT-TASEP is an indicator of better functionalization of TASEP by amine-silane than by mercaptosilane.

Figure 5 shows TG/DTA curves of the TASEP, MTASEP and APT-TASEP sepiolite samples. It should be noted that there is no exothermic peak at about $820{ }^{\circ} \mathrm{C}$ [15] on DTA curves, which would correspond to the phase transformation of sepiolite to enstatite. This is indica- 


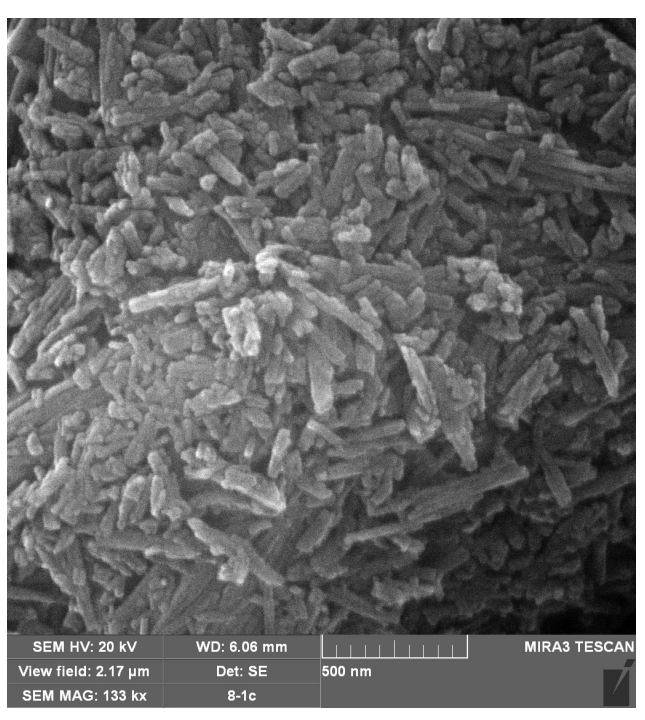

(a)

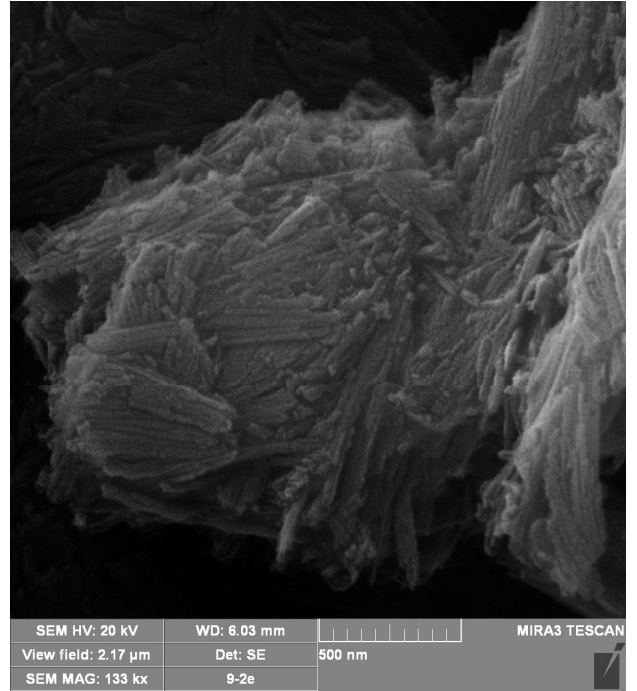

(b)

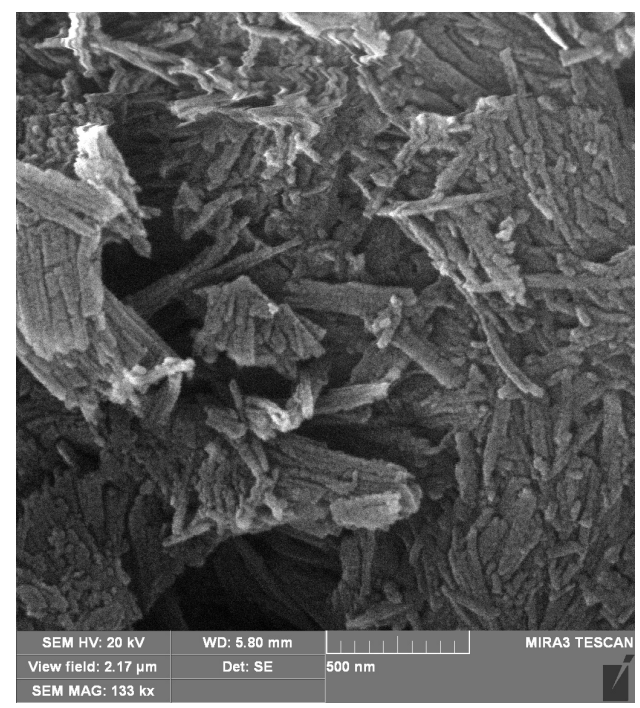

(c)

Figure 1. SEM Micrographs of TASEP (a), MTASEP (b) and APT-TASEP (c).

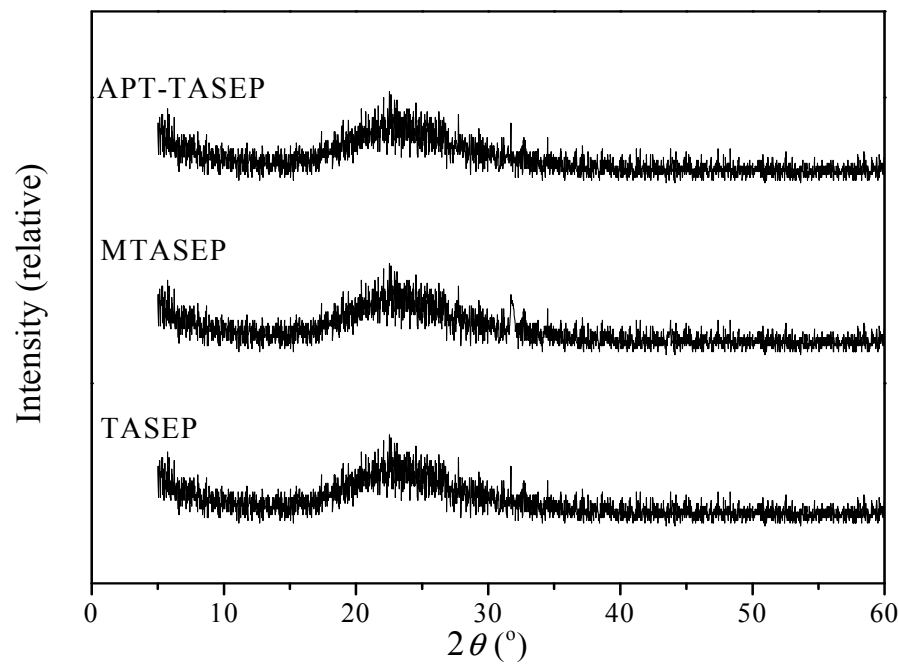

Figure 2. X-Ray diffractograms of the TASEP, MTASEP, and APT-TASEP samples. 


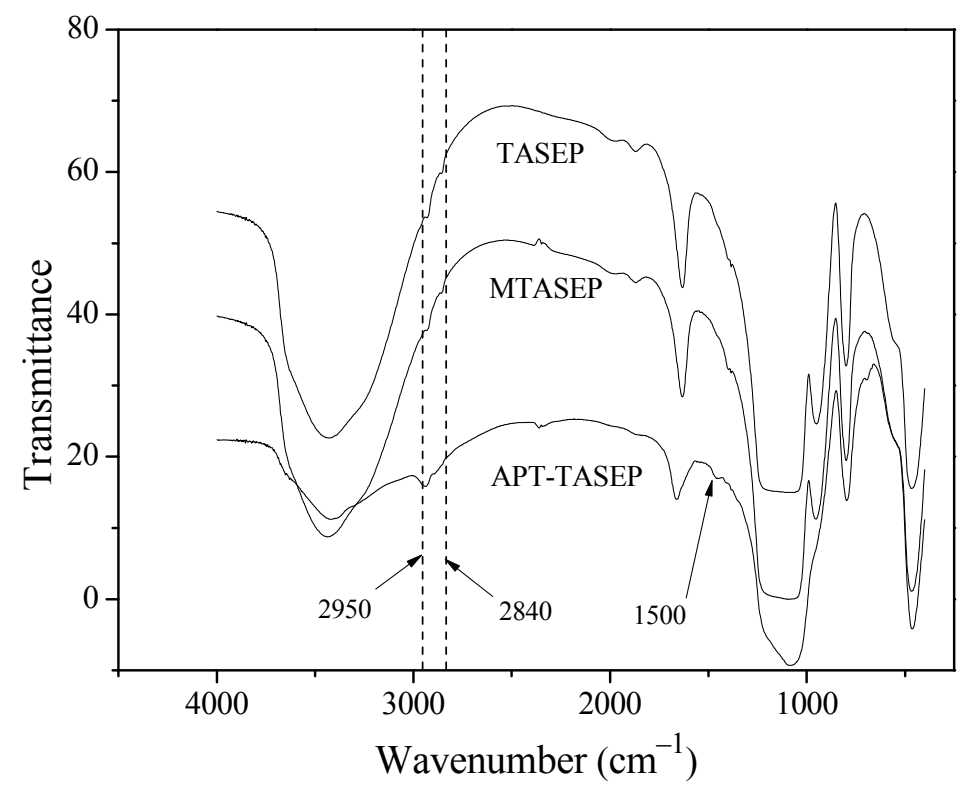

Figure 3. FT-IR spectra of the TASEP, MTASEP and APT-TASEP samples.

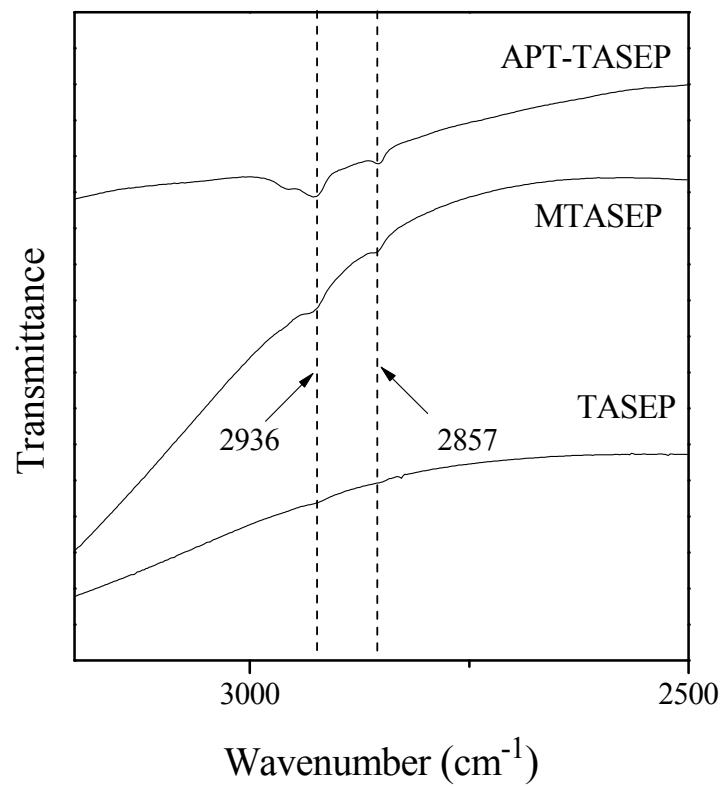

Figure 4. $3200-2500 \mathrm{~cm}^{-1}$ region of the FT-IR spectra of TASEP, MTASEP, and APT-TASEP.

tion of destruction of sepiolite structure during thermal-acid activation.

According to DTA curves in Figure 5, the two characteristic regions can be noticed: endothermic, from room temperature to $\sim 200{ }^{\circ} \mathrm{C}$, and exothermic, from $\sim 200$ to approximately $\sim 700{ }^{\circ} \mathrm{C}$. The weight loss in the first region, due to dehydratation $[26,36]$, is approximately the same for all samples, but slightly lower for APT-TASEP (3.5 wt.\%) than for TASEP (4.2 wt.\%) and MTASEP (5.6 wt.\%). On the other hand, the weight loss in the second region is much higher for APT-TASEP (16.6 wt.\%) than for TASEP (4.0 wt.\%) and MTASEP (5.3 wt.\%). The weight loss in the second region is primarily due to combustion of the organic matter, i.e., amine-silane or mercapto-silane [28,33,37]. Bearing in mind the molar mass of amine-silane, 209 $\mathrm{g} / \mathrm{mol}$, and mercapto-silane, $185 \mathrm{~g} / \mathrm{mol}$, it can be said that higher weight loss of APT-TASEP in the second region compared to MTASEP is primarily the result of much better functionalization of TASEP by amine-silane than by mercapto-silane.

Table 1 shows the textural properties of the TASEP, MTASEP and APT-TASEP samples. The results show that mercapto functionalization of TASEP leads to slight decreases in specific surface area, mesopore volume and micropore volume, while amine functionalization leads to significant decrease of these parameters.

Such changes of the textural parameters of TASEP by functionalization, especially micropore volume, can be explained by the size of organosilane molecules, i.e., the possibility of organosilane molecule to enter into the pores of TASEP.

In the case of APT-TASEP, it can be assumed that the large molecules of amine-silane entered and closed micropores [28,37-39] of TASEP during amine functionalization which caused a decrease of porosity, mainly microporosity, and consequently specific surface area. The decrease of microporosity of APT-TASEP compared to the TASEP causes the increase of the maximum and mean pore diameter of the APT-TASEP compared to the TASEP. Due to micropore closing, the content of pore water in APT-TASEP is lower than in TASEP and MTASEP, and consequently weight loss is lower due to dehydration (Figure 5).

According to the textural parameters of the MTASEP and TASEP (Table 1), a slight decrease of porosity of MTASEP compared to TASEP can be seen, so it could be 


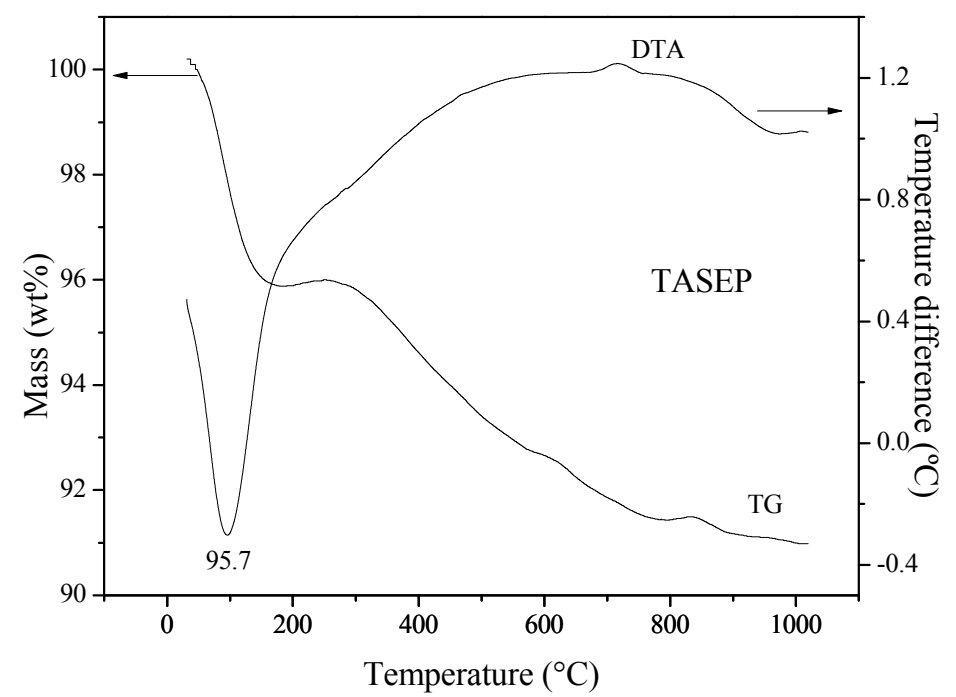

(a)

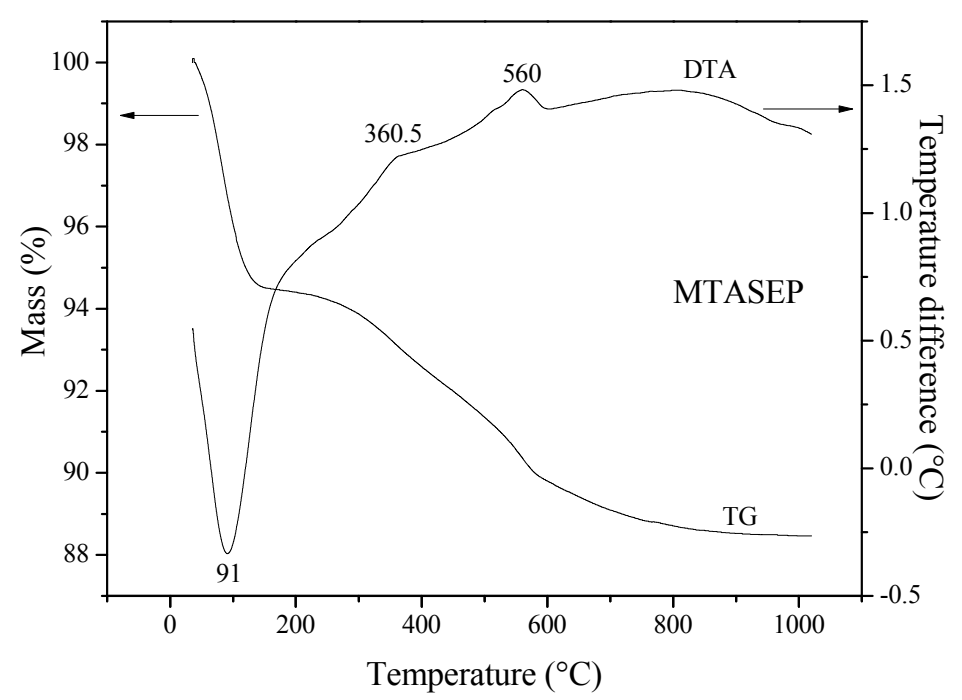

(b)

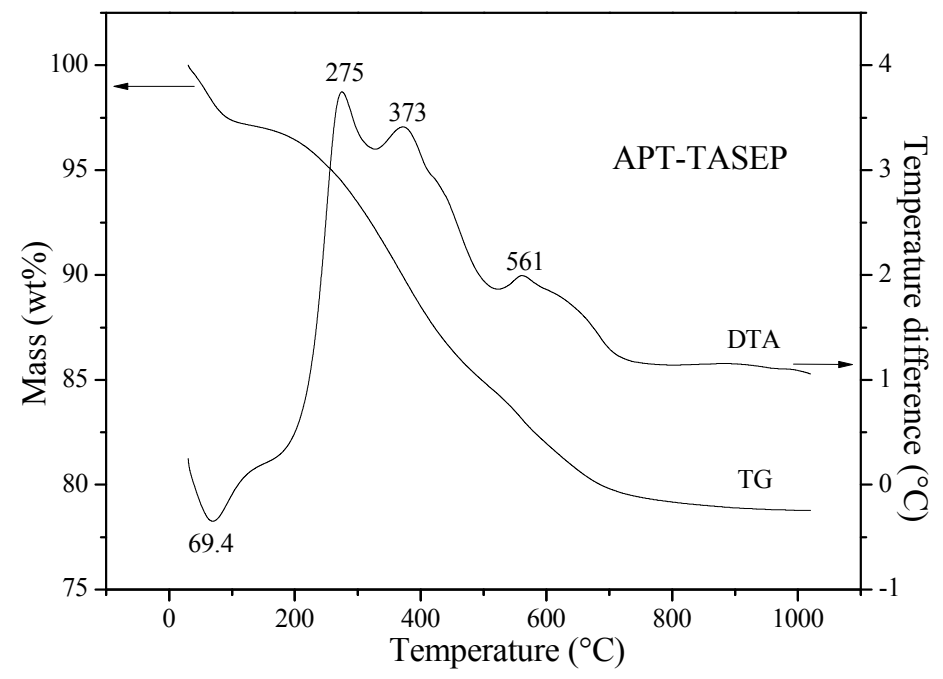

(c)

Figure 5. TG/DTA curves of the a) TASEP, b) MTASEP and c) APT-TASEP samples. 
Table 1. The textural parameters of the TASEP, MTASEP, and APT-TASEP samples

\begin{tabular}{lcc}
\hline Parameter & TASEP & MTASEP \\
\hline Specific surface area, $S_{\mathrm{BET}} / \mathrm{m}^{2} \mathrm{~g}^{-1}$ & 449 & 403 \\
Micropore volume, $V_{\text {micropore }} / \mathrm{cm}^{3} \mathrm{~g}^{-1}$ & 0.415 & 0.349 \\
Mesopore volume, $V_{\text {mesopore }} / \mathrm{cm}^{3} \mathrm{~g}^{-1}$ & 0.571 & 0.396 \\
Maximum pore diameter, $D_{\max } / \mathrm{nm}$ & 3 & 4 \\
Mean pore diameter, $D_{\text {mean }} / \mathrm{nm}$ & 7 & 8.058 \\
\hline
\end{tabular}

assumed that the entry of relatively small molecules mercapto-silane in pores of TASEP did not cause a significant reduction in volume of micropores and mesopores. The maximum and mean pore diameters of MTASEP are similar to those of TASEP indicating that micropores of the TASEP were not closed during the mercapto functionalization of TASEP.

The results of determination of the point of zero charge, $\mathrm{pH}_{\mathrm{pzc}}$ for the samples TASEP, MTASEP and APTTASEP are shown in Figure 6. The $\mathrm{pH}_{\mathrm{pzc}}$ of APT-SEP (Figure $6 \mathrm{c}$ ) was determined as the $\mathrm{pH}$ value of the plateau of $\mathrm{pH}_{\text {final }}$ vs. $\mathrm{pH}_{\text {initial }}$ dependence, while the $\mathrm{pH}_{\mathrm{pzc}}$ of TASEP and MTASEP was obtained as $\mathrm{pH}_{\text {final }}$ vs. $\mathrm{pH}_{\text {initial }}$ curves inflection (Figure $6 a$ and $b$, respectively). To precisely define the curve inflection, the $\mathrm{pH}_{\mathrm{pzc}}$ of TASEP and MTASEP were determined for two solid/liquid ratio.

From Figure 6 it is obvious that the $\mathrm{pH}$ value of the plateau or inflexion of the $\mathrm{pH}_{\text {final }} v s$. $\mathrm{pH}_{\text {initial }}$ dependence remains constant with changing concentration of $\mathrm{KNO}_{3}$ solution, which means that $\mathrm{KNO}_{3}$ is an indifferent electrolyte. In that way, the common plateau obtained at a $\mathrm{pH}$ value of $9.5 \pm 0.1$ for APT-TASEP corresponds to the $\mathrm{pH}_{\mathrm{pzc}}$ of the APT-TASEP. In addition, in the case of $\mathrm{pH}_{\mathrm{pzc}}$ of TASEP and MTASEP determination, the position of curve inflection was independent of solid/liquid ratio and values of $\mathrm{pH}_{\mathrm{pzc}}$ of TASEP and MTASEP were determined as $5.0 \pm 0.1$ and $4.7 \pm 0.1$, respectively.

The results of determination of the point of zero charge showed that acid-base properties of functionalized sepiolite were very much depended on the type of organosilane used for functionalization. The value of the point of zero charge of APT-TASEP was much higher than that of MTASEP, because amine-silane contains more basic groups $\left(-\mathrm{NH}_{2}\right.$ and $\left.-\mathrm{NH}-\right)$ than mercaptosilane (-SH). The acid-base properties of MTASEP are very similar to that of TASEP, because (-SH) group has similar acidity as $(-\mathrm{OH})$ group. In addition, the buffer capacity APT-TASEP is much higher than that of MTASEP and TASEP. In the wide range of $\mathrm{pH}_{\text {initial, }}$ the final $\mathrm{pH}$ values were constant and equal to $\mathrm{pH}_{\mathrm{pzc}}$ of APT-TASEP. Just in the range below the initial $\mathrm{pH} \sim 4.0$, the final $\mathrm{pH}$ values were less than $\mathrm{pH}_{\mathrm{pzc}}$ for APT-TASEP and the surface charge of APT-TASEP could become positive.
The adsorption of $\mathrm{Cr}(\mathrm{VI})$ onto mercapto-silane and amine-silane functionalized thermo-acid activated sepiolite samples

The results of preliminary experiments showed that adsorption capacity of TASEP for $\mathrm{Cr}(\mathrm{VI})$ is very low, as in the case of natural and acid-activated sepiolite [13]. Therefore, adsorption onto functionalized samples MTASEP and APT-TASEP was investigated and presented in this study.

The adsorption experiments were done at different initial $\mathrm{pH}$ values. During equilibration of adsorbent with ion solution, the $\mathrm{pH}$ value of solution can be changed due to: protonation/deprotonation of surface functional groups of adsorbent, interaction of $\mathrm{H}^{+} / \mathrm{OH}^{-}$with ions in the solution, specific adsorption of adsorbent, etc. Therefore, in order to assess the influence of $\mathrm{pH}$ on adsorption, it is not enough to adjust initial $\mathrm{pH}$ value, but it is necessary to follow the changes of $\mathrm{pH}$ during adsorption.

The dependence of the final solution $\mathrm{pH}$ value $\left(\mathrm{pH}_{\text {final }}\right)$, during equilibration of the $\mathrm{Cr}(\mathrm{VI})$ solution with MTASEP and APT-TASEP samples on the initial concentration of $\mathrm{Cr}(\mathrm{VI})$ solution are shown in Figure $7 \mathrm{a}$ and $\mathrm{b}$, respectively. The dependence of the adsorbed amount of $\mathrm{Cr}(\mathrm{VI}), q_{\mathrm{e}}$, on the equilibrium concentration of $\mathrm{Cr}(\mathrm{VI})$ solution, $c_{e}$, is shown on Figure $8 a$ for MTASEP and $8 b$ for APT-TASEP.

During equilibration of the $\mathrm{Cr}(\mathrm{VI})$ solutions with MTASEP and APT-TASEP at $\mathrm{pH}_{\text {initial }} 2.0$ (Figure 7), the $\mathrm{pH}_{\text {final }}$ remained nearly constant with an increase in initial $\mathrm{Cr}(\mathrm{VI})$ concentration and approximately equal to $\mathrm{pH}_{\text {initial, }}$ due to high acid conditions in the suspension of both samples. The similar dependence of $\mathrm{pH}_{\text {final }}$ on $\mathrm{Cr}(\mathrm{VI})$ concentration was obtained for MTASEP for $\mathrm{pH}_{\text {initial }}$ 3.0. But, in the case of APT-TASEP at $\mathrm{pH}_{\text {initial }} 3.0$, as well as at $\mathrm{pH}_{\text {initial }} 4.5, \mathrm{pH}_{\text {final }}$ was much higher due to high buffer capacity of APT-TASEP. At low $\mathrm{Cr}(\mathrm{VI})$ concentration, $\mathrm{pH}_{\text {final }}$ was equal to $\mathrm{pH}_{\mathrm{pzc}}$ of APT-TASEP, but with the increase of $\mathrm{Cr}(\mathrm{VI})$ concentration $\mathrm{pH}_{\text {final }}$ decreased, which can be explained by deprotonation of $\mathrm{HCrO}_{4}^{-}$ions at $\mathrm{pH}>6.8\left(\mathrm{HCrO}_{4}^{-} \leftrightarrows \mathrm{H}^{+}+\mathrm{CrO}_{4}{ }^{2-}\right)$ [1]. During $\mathrm{Cr}(\mathrm{VI})$ adsorption on MTASEP at $\mathrm{pH}_{\text {initial }} 4.5$, final $\mathrm{pH}$ values were not much higher than the initial $\mathrm{pH}$, because of low buffer capacity of the adsorbent. A slight increase of $\mathrm{pH}_{\text {final }}$ with the increase of $\mathrm{Cr}(\mathrm{VI})$ con- 


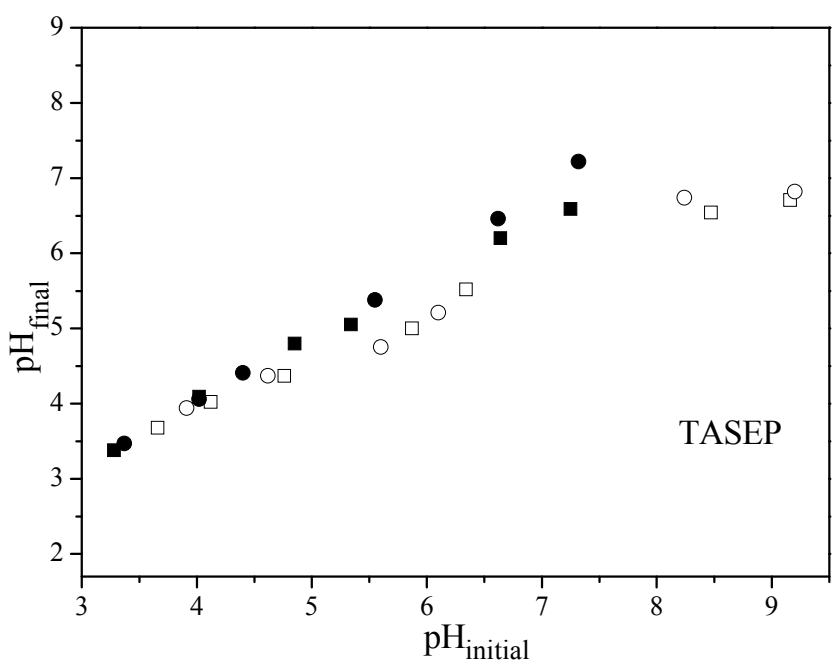

(a)

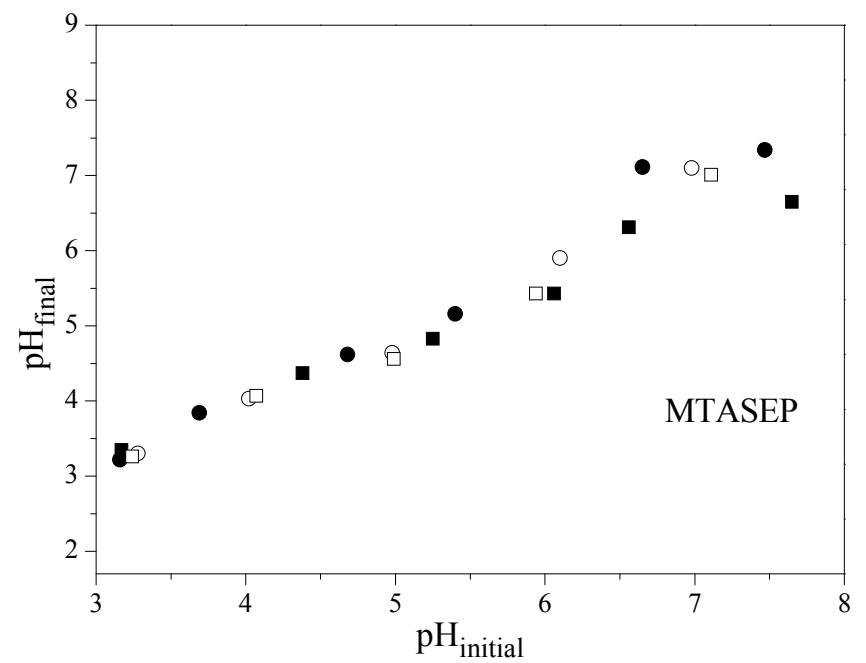

(b)

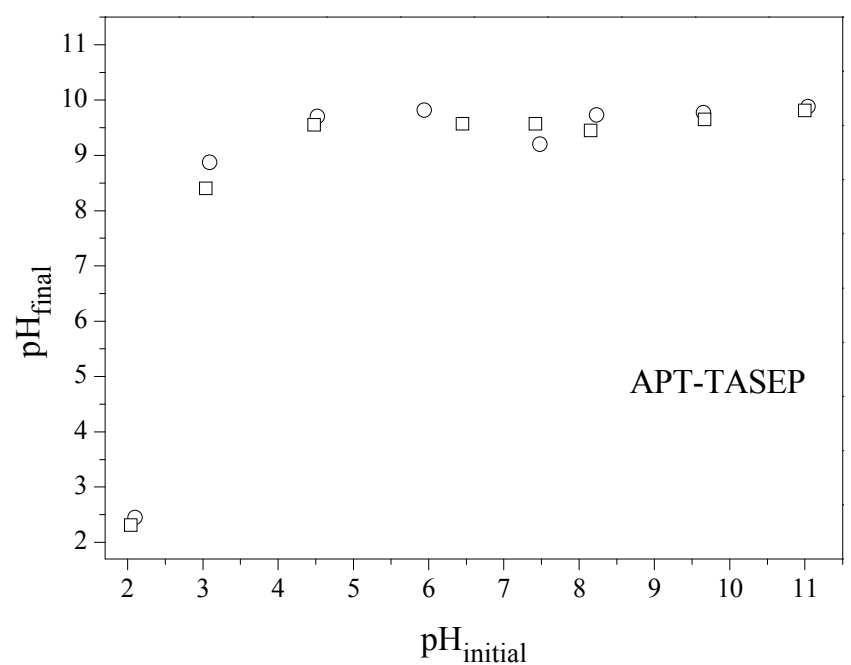

(c)

Figure 6. Dependence of $\mathrm{pH}_{\text {final }}$ on $\mathrm{pH}_{\text {initial }}$ during the equilibration: a) of $0.1 \mathrm{~g}$ of TASEP with $25 \mathrm{~cm}^{3}$ solution of (घ) $0.1 \mathrm{M} \mathrm{KNO_{3,3 }}(\bullet)$ $0.01 \mathrm{M} \mathrm{KNO}_{3}$ and $0.05 \mathrm{~g}$ of TASEP with $25 \mathrm{~cm}^{3}$ solution of (ㅁ) $0.1 \mathrm{M} \mathrm{KNO}_{3}$, (O) $0.01 \mathrm{M} \mathrm{KNO}_{3}$; b) of $0.1 \mathrm{~g}$ of MTASEP with $25 \mathrm{~cm}$ solution of (घ) $0.1 \mathrm{M} \mathrm{KNO}_{3},(\bullet) 0.01 \mathrm{M} \mathrm{KNO}_{3}$ and $0.05 \mathrm{~g}$ of MTASEP with $25 \mathrm{~cm}^{3}$ solution of (口) $0.1 \mathrm{M} \mathrm{KNO}_{3}$, (0) $0.01 \mathrm{M} \mathrm{KNO}_{3}$; c) of $0.05 \mathrm{~g}$ of APT-TASEP with $25 \mathrm{~cm}^{3}$ solution of (ㅁ) $0.1 \mathrm{M} \mathrm{KNO}_{3}$, (0) $0.01 \mathrm{M} \mathrm{KNO}_{3}$. 


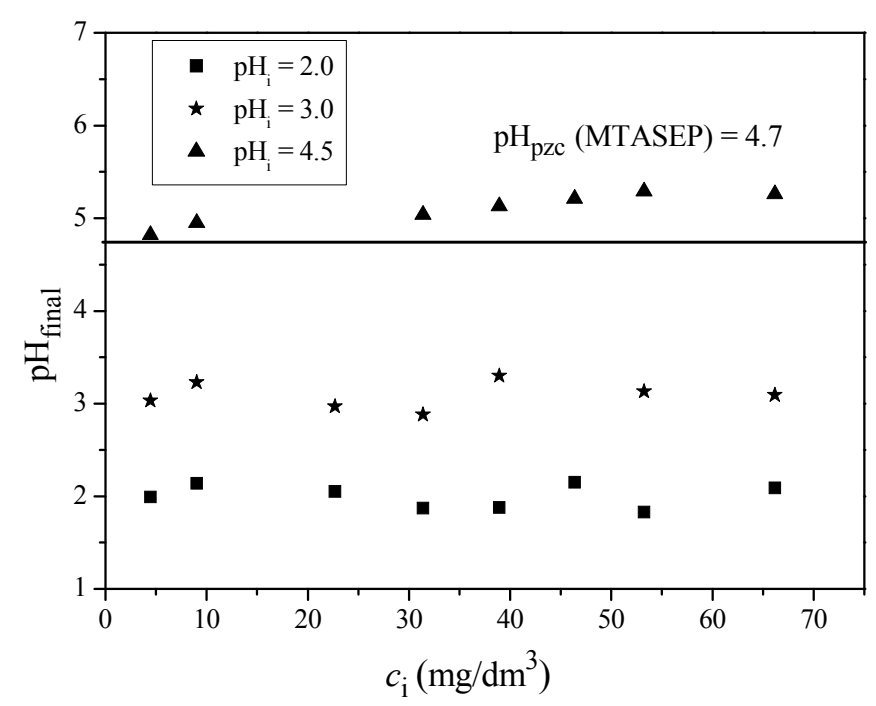

(a)

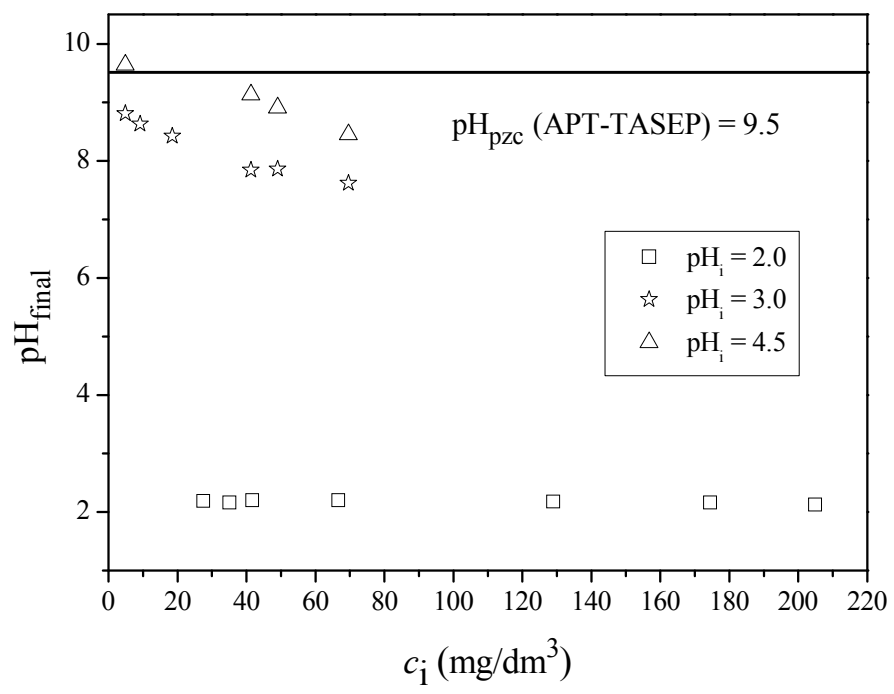

(b)

Figure 7. a) Dependence of the final solution $\mathrm{pH}$ value on the initial $\mathrm{Cr}(\mathrm{VI})$ concentration during the equilibration of $25 \mathrm{~cm}^{3}$ of $\mathrm{Cr}(\mathrm{VI})$ solution with $0.1 \mathrm{~g}$ of MTASEP at initial $\mathrm{pH}$ values 2.0, 3.0 and $4.5 ; b$ ) dependence of the final solution $\mathrm{pH}$ value on the initial $\mathrm{Cr}(\mathrm{VI})$ concentration during the equilibration of $25 \mathrm{~cm}^{3}$ of $\mathrm{Cr}(\mathrm{VI})$ solution with $0.05 \mathrm{~g}$ of APT-TASEP at initial pH values of 2.0, 3.0 and 4.5 .

centration can be explain by the increase of content of $\mathrm{HCrO}_{4}{ }^{-}$instead of $\mathrm{CrO}_{4}{ }^{2-}$ at lower $\mathrm{pH}$ values $(\sim 5)$.

The adsorption of $\mathrm{Cr}(\mathrm{VI})$ on functionalized sepiolites is dependent on $\mathrm{pH}$ of the solution which affects the surface charge of the adsorbent and the predominant species of $\mathrm{Cr}(\mathrm{VI})$ in solution.

It was found (Figure 8) that the amount of $\mathrm{Cr}(\mathrm{VI})$ ions adsorbed onto MTASEP slightly increased with $\mathrm{pH}_{\text {final }}$ decreasing from 5.2 (at $\mathrm{pH}_{\text {initial }} 4.5$ ) to 3.1 (at $\mathrm{pH}_{\text {initial }}$ 3.0) and 2.1 (at $\mathrm{pH}_{\text {initial }}$ 2.0). Thus, the amount of adsorbed $\mathrm{Cr}(\mathrm{VI})$ was higher at lower pHs (around 3.0 and 2.0) than at higher pHs (around 5.0), but the sorption capacity of MTASEP was a bit higher at $\mathrm{pHs} \sim 3.0$ than at $\mathrm{pHs} \sim 2.0$.

The results, shown in Figure $7 a$, indicate that at $\mathrm{pH}_{\text {initial }}$ of 2.0 and 3.0, $\mathrm{pH}_{\text {final }}$ were lower than $\mathrm{pH}_{\mathrm{pzc}}$ of
MTASEP (4.7), which means that the surface of MTASEP was positively charged due to protonation of the surface mercapto (-SH) groups. As the $\mathrm{pH}_{\text {final }}$ was lower than the $\mathrm{pH}_{\mathrm{pzc}}$ of MTASEP, the surface was more positively charged, due to the large number of protonated mercapto groups $\left(-\mathrm{SH}_{2}{ }^{+}\right)$. A higher positive charge of the surface of MTASEP cause higher electrostatic attraction between MTASEP surface [13,40-44] and $\mathrm{HCrO}_{4}^{-}$, which is predominant form of $\mathrm{Cr}(\mathrm{VI})$ in the solution of examined $\mathrm{pH}$ range [1].

It was shown $[13,45-47]$ that in very acidic conditions, at $\mathrm{pH}<3$, mercapto groups can reduce $\mathrm{Cr}(\mathrm{VI})$ to $\mathrm{Cr}(\mathrm{III})$, whereby the mercapto groups are oxidized into sulfonic groups $\left(-\mathrm{SO}_{3} \mathrm{H}\right)$ of high acidity. It can be supposed that at $\mathrm{pH}_{\text {initial }} 2.0$, due to very acidic conditions, sulfonic groups were weakly ionized, and $\mathrm{Cr}^{3+}$, formed 


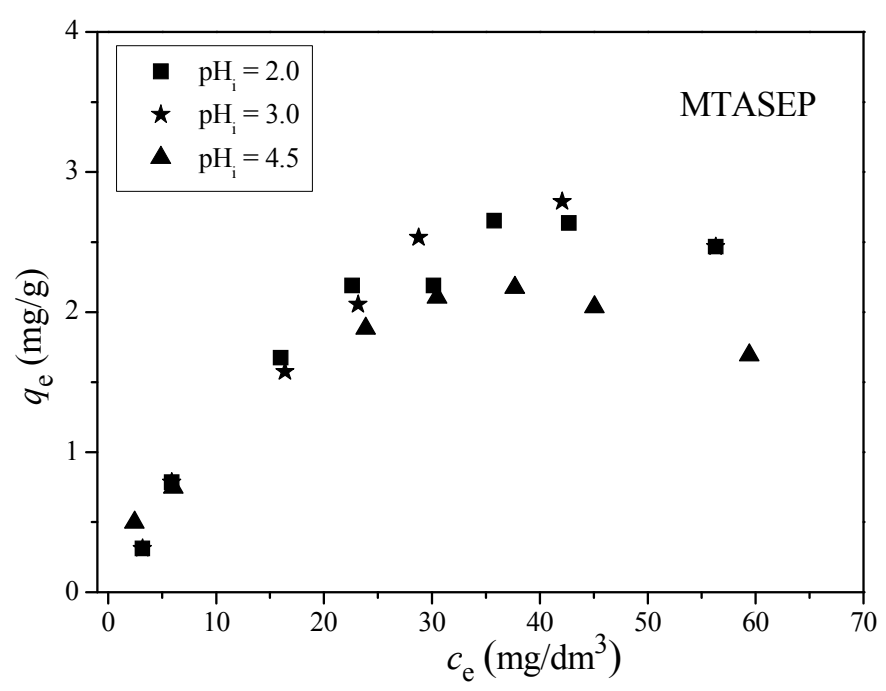

(a)

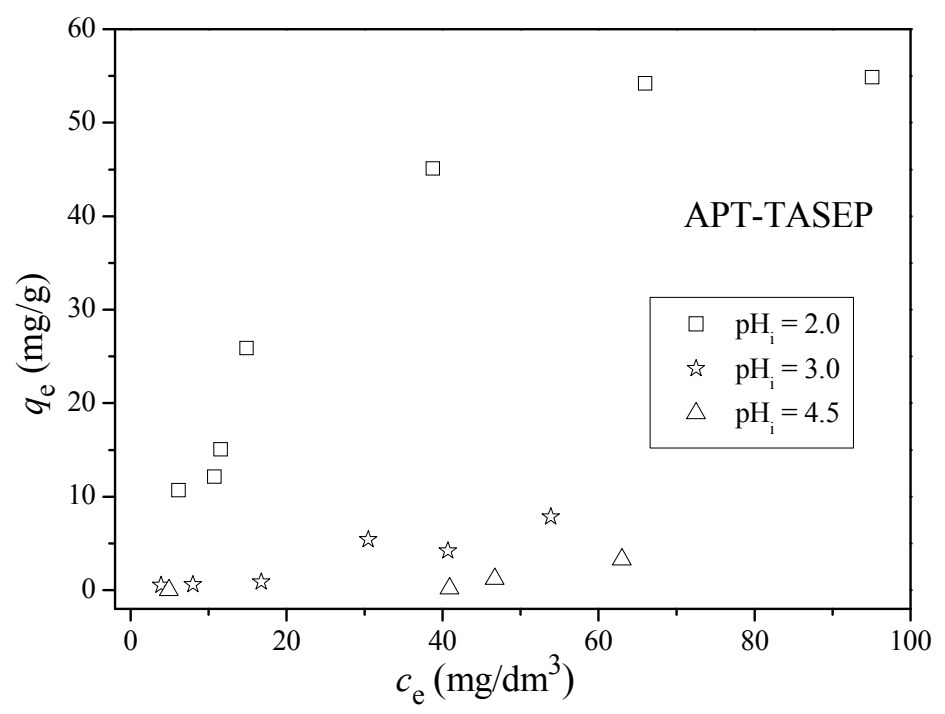

(b)

Figure 8. The adsorption isotherms of $\mathrm{Cr}(\mathrm{VI}):$ a) on MTASEP at initial pHs 2.0, 3.0 and 4.5 and b) on APT-TASEP at initial pHs 2.0, 3.0 and 4.5 .

by reduction of $\mathrm{Cr}(\mathrm{VI})$, were weakly adsorbed on the surface MTASEP, due to a very small number of $-\mathrm{SO}_{2} \mathrm{O}^{-}$ groups, that could bind the $\mathrm{Cr}^{3+}$ through electrostatic attraction. According to that, it was assumed that the predominant mechanism of removal of $\mathrm{Cr}(\mathrm{VI})$ from aqueous solutions, at initial $\mathrm{pH}$ value of 2.0 , was the electrostatic attraction between $\mathrm{HCrO}_{4}^{-}$from the solution and protonated mercapto $\left(-\mathrm{SH}_{2}{ }^{+}\right)$groups on the surface of the MTASEP.

On the other hand, at $\mathrm{pH}_{\text {initial }} 3.0$, the reduction of $\mathrm{Cr}(\mathrm{VI})$ to $\mathrm{Cr}^{3+}$ was lower than at $\mathrm{pH}_{\text {initial }} 2.0$, but due to a higher number of $-\mathrm{SO}_{2} \mathrm{O}^{-}$groups, formed by ionization of the $-\mathrm{SO}_{3} \mathrm{H}$ groups at higher $\mathrm{pH}$ value, it can be suppose that $\mathrm{Cr}^{3+}$ were better adsorbed on the surface MTASEP due to the electrostatic attraction between the $\mathrm{Cr}^{3+}$ and $-\mathrm{SO}_{2} \mathrm{O}^{-}$groups. Thus, it was assumed that the reduction of $\mathrm{Cr}(\mathrm{VI})$ to $\mathrm{Cr}(\mathrm{III})$ followed by removal of resulted $\mathrm{Cr}^{3+}$ gave the contribution to adsorption of chromium onto MTASEP at $\mathrm{pH}_{\text {initial }}$ 3.0. Therefore, the electrostatic attraction between $\mathrm{HCrO}_{4}{ }^{-}$and the protonated $-\mathrm{SH}_{2}^{+}$groups on the MTASEP surface, as well as reduction of $\mathrm{Cr}(\mathrm{VI})$ to $\mathrm{Cr}$ (III) followed by electrostatic attraction between $\mathrm{Cr}^{3+}$ and $-\mathrm{SO}_{2} \mathrm{O}^{-}$groups were possible mechanisms of $\mathrm{Cr}(\mathrm{VI})$ removal from solution at initial $\mathrm{pH}_{\text {initial }} 3.0$.

It can be seen from Figure $8 \mathrm{~b}$ that $\mathrm{Cr}(\mathrm{VI})$ adsorption onto APT-TASEP significantly increased with initial and final $\mathrm{pH}$ value decreasing to $\mathrm{pH} \sim 2$ and $\sim 2$.2, respectively. During the equilibration of APT-TASEP with $\mathrm{Cr}(\mathrm{VI})$ solution at $\mathrm{pH}_{\text {initial }} 2.0$, the final $\mathrm{pH}$ values were much lower than $\mathrm{pH}_{\mathrm{pzc}}$ of APT-TASEP, which means that the surface of APT-TASEP had high positive charge, due to 
protonation of the surface amine groups $(-\mathrm{NH}-$ and $\left.-\mathrm{NH}_{2}\right)[29,30,34,39,40,48-50]$. The presence of a large number of protonated amine groups on the surfaces of the APT-TASEP favoured $\mathrm{HCrO}_{4}{ }^{-}$adsorption by electrostatic attraction $[8,13,29,40,48-50]$.

At higher $\mathrm{pH}_{\text {initial }}, 3.0$ and 4.5 , the $\mathrm{pH}_{\text {final }}$ of solutions were near the $\mathrm{pH}_{\mathrm{pzc}}$ of the APT-TASEP and the surface of APT-TASEP was less positively charged. Thus, electrostatic attractions between the surface and $\mathrm{Cr}(\mathrm{VI})$ anions were lower than at $\mathrm{pH}_{\text {initial }} 2.0$ and the amount of $\mathrm{Cr}(\mathrm{VI})$ removed from solution was also lower. The possible mechanism of $\mathrm{Cr}(\mathrm{VI})$ removal at those $\mathrm{pH}$ values is also the formation of hydrogen bonding between oxygen atoms of $\mathrm{CrO}_{4}{ }^{2-}$ (which is a predominant form of $\mathrm{Cr}(\mathrm{VI})$ at $\mathrm{pHs}$ approximately equal to $\mathrm{pH}_{\mathrm{pzc}}$ for APT-TASEP) and hydrogen atoms of non-protonated amine groups $[29,40]$.

According to the reported results, the amine functionalized thermo-acid activated sepiolite is a more effective adsorbent than mercapto functionalized thermo-acid activated sepiolite for $\mathrm{Cr}(\mathrm{VI})$, at all investigated initial solution $\mathrm{pH}$ values, especially at lower $\mathrm{pHs}$. Although TASEP mercapto functionalization leads to a slight decrease in the specific surface area and porosity, while the amino functionalization leads to a significant reduction in these parameters, the APT-TASEP showed a higher adsorption capacity than the MTASEP. It is obvious that the type of silane used for modification, e.g., its chain length and basicity of groups in silane that could be protonated, has a pronounced influence on adsorption capacity for $\mathrm{Cr}(\mathrm{VI})$. Similar results were obtained in our previous studies for the functionalised natural and acid-activated sepiolites [13,14]: adsorption capacities of amine-functionalized sepiolites were much higher than of mercapto functionalized sepiolites. The maximum adsorption capacities of the functionalized thermo-acid activated sepiolites are higher than those of the functionalized natural sepiolites $[13,14]$, but lower than those of the functionalized acid activated sepiolite, at the same conditions $(\mathrm{pH}$ and temperature). In this study, it was assumed that by thermo-acid activation of sepiolite, silica with high content of silanol groups at the surface could be obtained, which could enable higher degree of functionalization by covalent grafting of silane and consequently higher adsorption capacity for anionic species of chromium (VI) compared to functionalized acid activated and natural sepiolite. However, this was not the case. The lower adsorption capacities of functionalized thermoacid activated sepiolites compared to functionalized acid activated sepiolites can be explained by the higher degree of condensation of surface silanol groups of thermo-acid activated sepiolites, which caused a decrease in the number of silanol groups at the surface for silane grafting.

\section{CONCLUSION}

The removal of $\mathrm{Cr}(\mathrm{VI})$ from aqueous solution using adsorbents obtained by covalent grafting of mercaptosilane and amine-silane onto thermo-acid activated sepiolite was studied.

Based on the presented results, it was concluded that the structure as well as fibre morphology of the thermo-acid activated sepiolite were preserved during organosilane functionalization.

FT-IR and DTA/TG results showed much better functionalization of thermo-acid activated sepiolite by amine-silane than by mercapto-silane.

According to the value of the point of zero charge, $\mathrm{pH}_{\mathrm{pzc}}$, it was shown that amine-silane gave a basic character to the surface and caused the $\mathrm{pH}_{\mathrm{pzc}}$ shift from $5.0\left(\mathrm{pH}_{\mathrm{pzc}}\right.$ of unfunctionalized sample) to $9.5\left(\mathrm{pH}_{\mathrm{pzc}}\right.$ of amine-functionalized sample), while the $\mathrm{pH}_{\mathrm{pzc}}$ of mercapto-silane functionalized sample (4.7) is slightly lower than $\mathrm{pH}_{\mathrm{pzc}}$ of unfunctionalized sample, due to similar acidity of their surface groups (-SH and $-\mathrm{OH})$.

In addition, the specific surface area, pore volume, maximum and mean pore diameters of amine functionalized sample were reduced, while these textural parameters of the mercapto functionalized sample were similar to those of parent sample.

The amine functionalized thermo-acid activated sepiolite showed a higher adsorption capacity for $\mathrm{Cr}(\mathrm{VI})$ than the mercapto functionalized sample at all the studied initial $\mathrm{pH}$ values, especially at lower initial $\mathrm{pH}$ values. The electrostatic attraction of anionic $\mathrm{Cr}(\mathrm{VI})$ species with protonated amine/mercapto groups of functionalized samples is a possible mechanism of $\mathrm{Cr}(\mathrm{VI})$ removal, at $\mathrm{pH}$ values of solution below the point of zero charge of adsorbent. The formation of hydrogen bonds between oxygen atoms of oxyanion species of $\mathrm{Cr}(\mathrm{VI})$ and hydrogen atoms of amine groups, at $\mathrm{pH}$ values of solution close to the $\mathrm{pH}_{\mathrm{pzc}}$ of amine functionalized sample could be another possible mechanisms of $\mathrm{Cr}(\mathrm{VI})$ removal by amine-silane funcionalised sample. In the case of mercapto-functionalized sample, the reduction of $\mathrm{Cr}(\mathrm{VI})$ by mercapto groups to $\mathrm{Cr}^{3+}$, followed by their electrostatic interaction with the sulfonate group, obtained by oxidation of the mercapto groups, is a possible mechanism at lower solution $\mathrm{pH}$ values.

\section{Acknowledgements}

The authors wish to acknowledge the financial support for this research from the Ministry of Education, Science and Technological Development of the Republic of Serbia through the project III45019.

\section{REFERENCES}

[1] D. Mohan, C.U. Pittman Jr., Review: activated carbons and low cost adsorbents for remediation of tri- and 
hexavalent chromium from water, J. Hazard. Mater., B 137 (2006) 762-811.

[2] M.B. Fritzen, A.J. Souza, T.A. G. Silva, L. Souza, R.A. Nome, H.D. Fiedler, F. Nome, Distribution of hexavalent $\mathrm{Cr}$ species across the clay mineral surface-water interface, J. Colloid Interf. Sci. 296 (2006) 465-471.

[3] B.S. Krishna, D.S.R. Murty, B.S. Prakash Jai, Surfactantmodified clay as adsorbent for chromate, Appl. Clay Sci. 20 (2001) 65-71.

[4] O. Maryuk, S. Pikus, E. Olszewska, M. Majdan, H. Skrzypek, E. Zięba, Benzyldimethyloctadecylammonium bentonite in chromates adsorption, Mater. Lett. 59 (2005) 2015-2017.

[5] Y. Bayrak, Y. Yesiloglu, U. Gecgel, Adsorption behavior of $\mathrm{Cr}(\mathrm{VI})$ on activated hazelnut shell ash and activated bentonite, Micropor. Mesopor. Mat. 91 (2006) 107-110.

[6] B. Sarkar, Y. Xi, M. Megharaj, G.S.R. Krishnamurti, D. Rajarathnam, R. Naidu, Remediation of hexavalent chromium through adsorption by bentonite based Arquad $^{\circledR}$ 2HT-75 organoclays, J. Hazard. Mater. 183 (2010) 87$-97$.

[7] A. A. Atia, Adsorption of chromate and molybdate by cetylpyridinium bentonite, Appl. Clay Sci. 41 (2008) 73-84 .

[8] P. Yuan, M. Fan, D. Yanga, H. He, D. Liua, A. Yuan, J.X. Zhu, T.H. Chen, Montmorillonite-supported magnetite nanoparticles for the removal of hexavalent chromium $[\mathrm{Cr}(\mathrm{VI})]$ from aqueous solutions, J. Hazard. Mater. 166 (2009) 821-829.

[9] N. Rajesh, B.G. Mishra, P.K. Pareek, Solid phase extraction of chromium(VI) from aqueous solutions by adsorption of its diphenylcarbazide complex on a mixed bed adsorbent (acid activated montmorillonite-silica gel) column, Spectrochim. Acta, A 69 (2008) 612-618.

[10] A. Benhammou, A. Yaacoubi, L. Nibou, B. Tanouti, Chromium(VI) adsorption from aqueous solution onto Moroccan Al-pillared and cationic surfactant stevensite, J. Hazard. Mater. 140 (2007) 104-109.

[11] Y. Huang, X. Ma, G. Liang, Y. Yan, S. Wang, Adsorption behavior of $\mathrm{Cr}(\mathrm{VI})$ on organic-modified rectorite, Chem. Eng. J. 138 (2008) 187-193.

[12] H. Hong, W.-T. Jiang, X. Zhang, L. Tie, Z. Li, Adsorption of $\mathrm{Cr}(\mathrm{VI})$ on STAC-modified rectorite, Appl. Clay Sci. 42 (2008) 292-299.

[13] V. Marjanović, S. Lazarević, I. Janković-Častvan, B. Potkonjak, Đ. Janaćković, R. Petrović, Chromium(VI) removal from aqueous solutions using mercaptosilane functionalized sepiolites, Chem. Eng. J. 166 (2011) 198-206.

[14] V. Marjanović, S. Lazarević, I. Janković-Častvan, B. Jokić, Dj. Janaćković, R. Petrović, Adsorption of chromium(VI) from aqueous solutions onto amine-functionalized natural and acid-activated sepiolites, Appl. Clay Sci., submitted.

[15] S. Lazarević, I. Janković-Častvan, D. Jovanović, S. Milonjić, Dj. Janaćković, R. Petrović, Adsorption of $\mathrm{Pb}^{2+}, \mathrm{Cd}^{2+}$ and $\mathrm{Sr}^{2+}$ onto natural and acid-activated sepiolites, Appl. Clay Sci. 37 (2007) 47-57.
[16] M. Radojević, V. Jović, D. Vitorović, Study of sepiolite from Goleš (Kosovo, Yugoslavia). I. Sorption capacity, J. Serb. Chem. Soc. 67(7) (2002) 489-497.

[17] M. Radojević, V. Jović, D. Karaulić, D. Vitorović, Study of sepiolite from Goleš (Kosovo, Yugoslavia). II. Acid activation, J. Serb. Chem. Soc. 67(7) (2002) 499-506.

[18] J. L. Valentín, M. A. López-Manchado, A. Rodríguez, P. Posadas, L. Ibarra, Novel anhydrous unfolded structure by heating of acid pre-treated sepiolite, Appl. Clay Sci. 36 (2007) 245-255.

[19] M.A. Vicente Rodriguez, J. de D. Lopez Gonzalez, M.A. Bañares Muñoz, Acid activation of a Spanish sepiolite: physicochemical characterization, free silica content and surface areaof products obtained, Clay Miner. 29 (1994) 361-367.

[20] A.J. Aznar, E. Gutiérrez, P. Díaz, A. Alvarez, G. Poncelet, Silica from sepiolite: Preparation, textural properties, and use as support to catalysts, Micropor. Mat. 6 (1996) 105-114.

[21] E.P. Barrett, L.G. Joyner, P.P. Halenda, The deter-mination of pore volume and area distributions in porous substances. I. Computations from nitrogen isotherms, J. Am. Chem. Soc. 73 (1951) 373-380.

[22] M.L. Pinto, A.S. Mestre, A.P. Carvalho, J. Pires, Comparison of methods to obtain micropore size distributions of carbonaceous materials from $\mathrm{CO}_{2}$ adsorption based on the Dubinin-Radushkevich isotherm, Ind. Eng. Chem. Res. 49 (2010) 4726-4730.

[23] S.K. Milonjić, A.Lj. Ruvarac, M.V. Šušić, The Heat Immersion of Natural Magnetite in Aqueous Solution, Thermochim. Acta 11 (1975) 261-266.

[24] S. Lazarević, Ž. Radovanović, Dj. Veljović, A. Onjia, Dj. Janaćković, R. Petrović, Characterization of sepiolite by inverse gas chromatography at infinite and finite surface coverage, Appl. Clay Sci. 43 (2009) 41-48.

[25] M. Alkan, G. Tekin, H. Namli, FTIR and zeta potential measurements of sepiolite treated with some organosilanes, Micropor. Mesopor. Mat. 84 (2005) 75-83.

[26] M. Doğan, Y. Turhan, M. Alkan, H. Namli, P. Turan, Ö. Demirbaş, Functionalized sepiolite for heavy metal ions adsorption, Desalination 230 (2008) 248-268.

[27] C. del Hoyo, C. Dorado, M.S. Rodríguez-Cruz, M.J. Sánchez-Martín, Physico-chemical study of selected surfactant-clay mineral systems, J. Therm. Anal. Calorim. 94 (2008) 227-234.

[28] B. Lee, Y. Kim, H. Lee, J. Yi, Synthesis of functionalized porous silica via templating method as heavy metal ion adsorbents: the introduction of surface hydrophilicity onto the surface of adsorbents, Micropor. Mesopor. Mat. 50 (2001) 77-90.

[29] S. Denga, R. Bai, Removal of trivalent and hexavalent chromium with aminated polyacrylonitrile fibers: performance and mechanisms, Water Res. 38(9) (2004) 2424-2432.

[30] H. Yoshitake, E. Koiso, H. Horie, H. Yoshimura, Polyamine-functionalized mesoporous silicas: Preparation, structural analysis and oxyanion adsorption, Micropor. Mesopor. Mat. 85 (2005) 183-194. 
[31] H. Yang, R. Xu, X. Xue, F. Li, G. Li, Hybrid surfactanttemplated mesoporous silica formed in ethanol and its application for heavy metal removal, J. Hazard. Mater. 152 (2008) 690-698.

[32] X. Xu, B-Y. Gao, Q-Y. Yue, Q-Q. Zhong, Preparation and utilization of wheat straw bearing amine groups for the sorption of acid and reactive dyes from aqueous solutions, J. Hazard. Mater. 182 (2010) 1-9.

[33] P. Yin, Q. Xu, R. Qu, G. Zhao, Removal of transition metal ions from aqueous solutions by adsorption onto a novel silica gel matrix composite adsorbent, J. Hazard. Mater. 169 (2009) 228-232.

[34] M. Manzano, V. Aina, C.O. Areán, F. Balas, V. Cauda, M. Colilla, M.R. Delgado, M. Vallet-Regí, Studies on MCM41 mesoporous silica for drug delivery: Effect of particle morphology and amine functionalization, Chem. Eng. J. 137 (2008) 30-37.

[35] H. Sayılkan, S. Erdemoğlu, Ş. Şener, F. Sayılkan, M. Akarsu, M. Erdemoğl, Surface modifcation of pyrophyllite with amino silane coupling agent for the removal of 4-nitrophenol from aqueous solutions, J. Colloid Interf. Sci. 275 (2004) 530-538.

[36] G. Tartaglione, D. Tabuani, G. Camino, Thermall and morphological characterisation of organically modified sepiolite, Micropor. Mesopor. Mat. 107 (2008) 161-168.

[37] V. Zeleňák, M. Badaničová, D. Halamová, J. Čejka, A. Zukal, N. Murafa, G. Goerigk, Amine-modified ordered mesoporous silica: Effect of pore size on carbon dioxide capture, Chem. Eng. J. 144 (2008) 336-342.

[38] L. Niu, S. Deng, G. Yu, J. Huang, Efficient removal of $\mathrm{Cu}(\mathrm{II}), \mathrm{Pb}(\mathrm{II}), \mathrm{Cr}(\mathrm{VI})$ and $\mathrm{As}(\mathrm{V})$ from aqueous solution using an aminated resin prepared by surface-initiated atom transfer radical polymerization, Chem. Eng. J. 165 (2010) 751-757.

[39] J. Li, X. Miao, Y. Hao, J. Zhao, X. Sun, L. Wang, Synthesis, amino-functionalization of mesoporous silica and its adsorption of $\mathrm{Cr}(\mathrm{VI})$, J. Colloid Interf. Sci. 318 (2008) 309-314.

[40] J. Qiu, Z. Wang, H. Li, L. Xua, J. Peng, M. Zhai, C. Yang, J. $\mathrm{Li}, \mathrm{G}$. Wei, Adsorption of $\mathrm{Cr}(\mathrm{VI})$ using silica-based adsorbent prepared by radiation-induced grafting, J. Hazard. Mater. 166 (2009) 270-276.

[41] W. Liu, J. Zhang, C. Zhang, Y. Wang, Y. Li, Adsorptive removal of $\mathrm{Cr}(\mathrm{VI})$ by Fe-modified activated carbon prepared from Trapa natans husk, Chem. Eng. J. 162 (2010) 677-684.

[42] S. Edebali, E. Pehlivan, Evaluation of Amberlite IRA96 and Dowex $1 \times 8$ ion-exchange resins for the removal of $\mathrm{Cr}(\mathrm{VI})$ from aqueous solution, Chem. Eng. J. 161 (2010) 161-166.

[43] G. Moussavi, B. Barikbin, Biosorption of chromium(VI) from industrial wastewater onto pistachio hull waste biomass, Chem. Eng. J. 162 (2010) 893-900.

[44] G. Blázquez, F. Hernáinz, M. Calero, M.A. Martín-Lara, G. Tenorio, The effect of $\mathrm{pH}$ on the biosorption of $\mathrm{Cr}$ (III) and $\mathrm{Cr}$ (VI) with olive stone, Chem. Eng. J. 148 (2009) 473-479.

[45] T. Bai, X. Cheng, Preparation and characterization of 3mercaptopropyl trimethoxysilane self-assembled monolayers, J. Univ. Sci. Technol., B 15 (2008) 192.

[46] S. Shylesh, Sahida Sharma, S.P. Mirajkar, A.P. Singh, Silica functionalised sulphonic acid groups: synthesis, characterization and catalytic activity in acetalization and acetylation reactions, J. Mol. Catal., A 212 (2004) 219-228.

[47] J. Zhe, C. Xianhua, Characterization and tribological investigation of self-assembled MPTS-MPTES/RE composite films, J. Rare Earths 27 (2009) 490-495.

[48] K. Barquist, S. C. Larsen, Chromate adsorption on aminefunctionalized nanocrystalline silicalite-1, Micropor. Mesopor. Mater. 116 (2008) 365-369.

[49] Z. Yong-Gang, S. Hao-Yu, P. Sheng-Dong, H. Mei-Qin, Synthesis, characterization and properties of ethylenediamine-functionalized $\mathrm{Fe}_{3} \mathrm{O}_{4}$ magnetic polymers for removal of $\mathrm{Cr}(\mathrm{VI})$ in wastewater, J. Hazard. Mater. 182 (2010) 295-302.

[50] P.A. Kumar, M. Rayb, S. Chakraborty, Hexavalent chromium removal from wastewater using aniline formaldehyde condensate coated silica gel, J. Hazard. Mater. 143 (2007) 24-32. 


\section{IZVOD}

\section{ADSORPCIJA HROMA(VI) IZ VODENIH RASTVORA NA TERMO-KISELINSKI AKTIVIRANOM SEPIOLITU FUNKCIONALIZOVANOM AMINO-SILANOM I MERKAPTO-SILANOM}

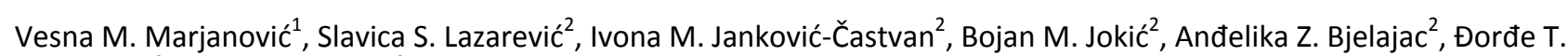
Janaćković ${ }^{2}$, Rada D. Petrović ${ }^{2}$

${ }^{1}$ Visoka poslovno-tehnička škola strukovnih studija, 31000 Užice, Srbija

${ }^{2}$ Tehnološko-metalurški fakultet Univerziteta u Beogradu, 11000 Beograd, Srbija

(Naučni rad)

Predmet ovog rada je funkcionalizacija termo-kiselinski aktiviranog sepiolita primenom (3-merkaptopropil)trimetoksisilana ili merkapto-silana i [3-(2-aminoetil-amino)propil]trimetoksisilana ili amino-silana, određivanje fizičko-hemijskih svojstava i proučavanje adsorpcije $\mathrm{Cr}(\mathrm{VI})$ iz vodenih rastvora na funkcionalizovanim materijalima pri različitim početnim $\mathrm{pH}$ vrednostima $(2,0,3,0$ i 4,5$)$. Za karakterizaciju funkcionalizovanih adsorbenata korišćene su: rendgenska difrakciona analiza (XRD), infracrvena spektroskopska analiza (FT-IR), termogravimetrijska i diferencijalno-termijska analiza (TG/DTA), skenirajuća elektronska mikroskopija (SEM), dok su adsorpciono-desorpcione izoterme azota korišćene za određivanje specifične površine, zapremine i raspodele veličina pora. Tačka nultog naelektrisanja adsorbenata je određena metodom uravnotežavanja posebnih proba. Rezultati karakterizacije su pokazali da je bolja funkcionalizacija termokiselinski aktiviranog sepiolita postignuta primenom amino-silana. Tokom funkcionalizacije organosilanima sačuvana je struktura i vlaknasta morfologija termokiselinski aktiviranog sepiolita. Kovalentnim vezivanjem amino-silana za površinu termo-kiselinski aktiviranog sepiolita povećava se bazni karakter površine, dok se u slučaju vezivanja merkapto-silana kiselo-bazna svojstva ne menjaju značajno. Specifična površina, zapremina i prečnici pora amino-silaniziranog uzorka su značajno manji u odnosu na nefunkcionalizovan uzorak, dok su kod merkapto-silaniziranog sepiolita približno isti kao kod polaznog materijala. Kapacitet adsorpcije $\mathrm{Cr}(\mathrm{VI})$ amino-silaniziranog adsorbenta je veći od kapaciteta merkapto-silaniziranog uzorka na svim ispitivanim početnim $\mathrm{pH}$ vrednostima $\mathrm{Cr}(\mathrm{VI})$ rastvora i naročito pri veoma niskoj početnoj $\mathrm{pH}$ vrednosti $(2,0)$. Dominantan mehanizam adsorpcije $\mathrm{Cr}(\mathrm{VI})$ pri početnoj $\mathrm{pH}$ rastvora 2,0 na amino-silaniziranom adsorbentu je elektrostatičko privlačenje između $\mathrm{Cr}(\mathrm{VI})$ anjona i protonovanih amino grupa, a pri višim početnim $\mathrm{pH}$ rastvora moguće je obrazovanje vodoničnih veza između $\mathrm{CrO}_{4}{ }^{2-} \mathrm{i}$ amino grupa. Adsorpcija $\mathrm{Cr}(\mathrm{VI})$ na merkapto-silaniziranom adsorbentu se zasniva na elektrostatičkim interakcijama između $\mathrm{Cr}(\mathrm{VI})$ anjona i protonovanih merkapto grupa, kao i redukciji $\mathrm{Cr}(\mathrm{VI})$ do $\mathrm{Cr}^{3+}$ merkapto grupama, uz elektrostatičko privlačenje redukcijom nastalih $\mathrm{Cr}^{3+}$ i sulfonatnih grupa dobijenih oksidacijom merkapto grupa.

Ključne reči: Termo-kiselinski aktiviran sepiolit • Funkcionalizacija • (3-Merkaptopropil)trimetoksi-silan • [3-(2-Aminoetilamino)propil]trimetoksi-silan • Adsorpcija $\bullet \operatorname{Hrom}(\mathrm{VI})$ 